\title{
Second-Line Treatment of Non-Small Cell Lung Cancer: Clinical, Pathological, and Molecular Aspects of Nintedanib
}

\author{
Luis Corrales ${ }^{1}$, Amanda Nogueira ${ }^{2}$, Francesco Passiglia ${ }^{2,3}$, Angela Listi ${ }^{3}$, \\ Christian Caglevic ${ }^{4}$, Marco Giallombardo ${ }^{2}$, Luis Raez ${ }^{5}$, Edgardo Santos ${ }^{6}$ and \\ Christian Rolfo ${ }^{2 *}$
}

${ }^{1}$ Clinical Oncology Department, Hospital San Juan de Dios, San José, Costa Rica, ${ }^{2}$ Phase I - Early Clinical Trials Unit, Oncology Department, Antwerp University Hospital, Center for Oncological Research (CORE), Antwerp University, Antwerp, Belgium, ${ }^{3}$ Department of Surgical, Oncological and Oral Sciences, Section of Medical Oncology, University of Palermo, Palermo, Italy, ${ }^{4}$ Medical Oncology Department, Instituto Oncológico Fundación Arturo López Pérez, Santiago, Chile, ${ }^{5}$ Thoracic Oncology Program, Memorial Cancer Institute, Memorial Health Care System, Pembroke Pines, FL, USA,

${ }^{6}$ Oncology Department, Lynn Cancer Institute, Boca Raton, FL, USA

Lung carcinoma is the leading cause of death by cancer in the world. Nowadays, most patients will experience disease progression during or after first-line chemotherapy demonstrating the need for new, effective second-line treatments. The only approved second-line therapies for patients without targetable oncogenic drivers are docetaxel, gemcitabine, pemetrexed, and erlotinib and for patients with target-specific oncogenes afatinib, osimertinib, crizotinib, alectinib, and ceritinib. In recent years, evidence on the role of antiangiogenic agents have been established as important and effective therapeutic targets in non-small cell lung cancer (NSCLC). Nintedanib is a tyrosine kinase inhibitor targeting three angiogenesis-related transmembrane receptors (vascular endothelial growth factor, fibroblast growth factor, and platelet-derived growth factor). Several preclinical and clinical studies have proven the usefulness of nintedanib as an anticancer agent for NSCLC. The most important study was the phase III LUME-Lung 1 trial, which investigated the combination of nintedanib with docetaxel for second-line treatment in advanced NSCLC patients. The significant improvement in overall survival and the manageable safety profile led to the approval of this new treatment in Europe. This review focuses on the preclinical and clinical studies with nintedanib in NSCLC.

Keywords: non-small cell lung cancer, angiogenesis, target therapy, nintedanib, second-line treatment, clinical trials

\section{INTRODUCTION}

Lung cancer is one of the most common malignancies in the world and is the leading cause of cancer-related deaths worldwide, accounting for 1.59 million deaths yearly. In the United States alone, an estimated 221,200 new cases of lung cancer were diagnosed in 2015, and 158,040 people will die of this disease (1-3). Non-small cell lung cancer (NSCLC) is the most frequent type of lung cancer, accounting for more than $80 \%$ of all cases, whereas small cell lung cancer represents $15-20 \%$ $(4,5)$. Most patients will experience disease progression during or after first-line chemotherapy, and 
there is a significant unmet need for new, effective second-line treatments. Currently, the only approved second-line therapies for patients who do not harbor identifiable driver oncogenes, such as epidermal growth factor receptor (EGFR) gene mutations or anaplastic lymphoma kinase $(A L K)$ gene translocations, are docetaxel, gemcitabine, pemetrexed (limited for non-squamous NSCLC), and erlotinib (6-9).

The majority of patients with NSCLC do not achieve prolonged disease control, and the 5 -year survival rate remains poor at $18.7 \%$ (1). Growing knowledge of NSCLC molecular pathobiology has led to the development of new treatments that target specific oncogenes (10) and have changed the natural history of the disease with a clear improvement of patient's survival (11). However, it is still characterized by a significantly low survival for second-line treatment $(12,13)$ with a median progression-free survival (PFS) from 2 to 3 months and a median survival rarely exceeding 8 months (14). The recognition of patients harboring EGFR mutations (EGFRm) or EML4-ALK translocation and displaying tyrosine kinase inhibitors (TKI) response rates of approximately $70 \%$ account an essential treatment. With the use of molecularly targeted therapies, such as erlotinib (15), afatinib (16) for EGFRm, osimertinib (17) for EGFRm T790, and crizotinib (18), alectinib, and ceritinib $(19,20)$ for ALK positive (Table 1), a higher response rates and prolonged PFS have been obtained when compared to chemotherapy in the first- and second-line setting (21).

Antiangiogenic agents have been established as important and effective therapeutic targets in many cancers, including NSCLC. Angiogenesis is one of the hallmarks of cancer and is critical for the growth, progression, and metastasis of many solid tumor types (22-24). Mechanisms that support the formation of neovasculature include vascular endothelial growth factor (VEGF), fibroblast growth factor (FGF), and platelet-derived growth factor (PDGF) signaling pathways (22, 25-27). To date, first-line bevacizumab remains the only approved antiangiogenic treatment in the therapeutic armamentarium for advanced NSCLC. Its use is restricted to patients with tumors with a non-squamous histology $(28,29)$.

In the Eastern Cooperative Oncology Group, 878 patients with recurrent or advanced NSCLC were recruited and assigned to paclitaxel/carboplatin chemotherapy alone or paclitaxel/carboplatin and bevacizumab. The addition of the anti-VEGF to a standard, platinum-based doublet regimen conferred a significant prolongation in overall survival (OS), PFS, and response rate in patients with NSCLC (28) (Table 1). Also, bevacizumab administered with paclitaxel showed a median PFS longer compared to docetaxel in second-third line of treatment (30) In the AVAiL trial, patients with non-squamous NSCLC were randomized to receive cisplatin/gemcitabine with or without bevacizumab and in a similar way, the results in this trial demonstrated an improvement in PFS versus placebo (31).

Furthermore, ramucirumab, a vascular endothelial growth factor receptor-2 (VEGFR2) inhibitor, was investigated as second-line therapy with docetaxel for stage IV NSCLC. Median OS and PFS were longer in the ramucirumab arm compared with the placebo arm (32) (Table 1). Even though VEGF is the most potent angiogenic molecule, the inhibition of the VEGF pathway with TKI or monoclonal antibodies is associated with a modest survival benefit.

The multikinases inhibitor sorafenib targets VEGFR2-3, PDGFR- $\beta$, c-kit, RAF, and FLT-3. In two phase II studies, it was determined an improvement in PFS and in OS when used as a single agent with respect to placebo (33) (Table 1). Furthermore, a phase I/II trial studied the effect of sorafenib combined with carboplatin/paclitaxel and showed a median PFS of 34 weeks with a good toxicity profile (34). However, two Phase III trials, ESCAPE and NEXUS trials, were conducted to confirm the efficacy and feasibility of the combination treatment. Unfortunately, neither of the trials met their primary endpoints $(35,36)$.

Sunitinib, an orally selective multitargeted TKI that inhibits PDGFR, KIT, FLT-3, and VEGFR, has also been evaluated in combination with both chemotherapy and erlotinib after failure of first-line platinum-based chemotherapy. CALGB 30704 randomized patients to pemetrexed alone, sunitinib alone, or the combination of pemetrexed/sunitinib as second-line therapy for advanced NSCLC (37) (Table 1). The results demonstrated a nonstatistically significant higher response rate in patients receiving pemetrexed/sunitinib and a better PFS and OS in the single agent pemetrexed arm. Also, two trials evaluated the combination of erlotinib and sunitinib, and no differences in PFS or OS were observed $(38,39)$.

Unfortunately, the activation of other angiogenic pathways has also developed drug resistance by the tumor. Molecules, such as FGF and PDGF, have been found upregulated in patients exhibiting acquired resistance to anti-VEGF treatment. The use of multitargeted anti-angiogenesis tyrosine kinase inhibitors (MATKIs) to achieve simultaneous inhibition of two or three angiogenic pathways has been proposed as a promising strategy for improved outcomes in NSCLC patients (40).

Nintedanib (Vargatef ${ }^{\circledR}$; BIBF 1120) is a novel, potent, oral, triple angiokinase inhibitor that targets VEGF receptors 1 to 3, PDGF receptors alpha and beta, and FGF receptors 1 to 3 (41-43), as well as members of the Src family and FLT-3 (43) (Figure 1).

\section{PRECLINICAL DEVELOPMENT}

Nintedanib was identified during a program for small molecule inhibitors of angiogenesis, and studies were extended to various solid tumors (43). Recent evidence shows that nintedanib is a potent endothelial cell proliferation inhibitor with a good safety profile, proven in both in vitro and in vivo studies.

This molecule, an indolinone derivative, occupies the adenosine triphosphate-binding sites in the kinase domain of pro-angiogenic receptors previously mentioned, inhibiting the downstream signaling pathways. Overall, the spectrum is fairly restricted (VEGFR-1, VEGFR-2, VEGFR-3, FGFR-1, 2, 3, PDGFR- $\alpha$ and $\beta$, FLT3, and SRC family member) and has shown low cross-reactivity with other human kinases $(41,43,44)$. Peak plasma concentrations of nintedanib are reached $2-4 \mathrm{~h}$ after oral administration and have a terminal half-life of 10-15 h. Also, it is metabolized largely via hydrolytic cleavage by esterases; cytochrome $\mathrm{P} 450$ pathways have a minor role in the metabolism of the MATKI. The major route of elimination is fecal/biliary excretion (45). 
TABLE 1 | Early development of Target therapy in non-small cell lung cancer (NSCLC).

\begin{tabular}{|c|c|c|c|c|c|c|c|}
\hline Drug mechanism & Reference & $N$ total & Drug & Comparator & $\begin{array}{l}\text { Median overall survival } \\
\text { (OS) }\end{array}$ & $\begin{array}{l}\text { Median OS } \\
\text { regarding sequential } \\
\text { combination of } \\
\text { EGFR-TKI and } \\
\text { chemotherapy }\end{array}$ & $\begin{array}{l}\text { Median progression-free } \\
\text { survival (PFS) }\end{array}$ \\
\hline \multirow[t]{5}{*}{$\begin{array}{l}\text { Tyrosine kinase } \\
\text { inhibitors }\end{array}$} & Zhou et al. (15) & 154 & Erlotinib & Gemcitabine + carboplatin & 22.8 versus 27.2 months $^{\mathrm{a}}$ & $\begin{array}{l}29.7 \text { versus } 20.7 \\
\text { or } 11.2 \text { months, } \\
\text { respectively } \\
(p<0.0001)\end{array}$ & NA \\
\hline & Yang et al. (16) & 631 & Afatinib & $\begin{array}{l}\text { Cisplatin/pemetrexed } \\
\text { OR } \\
\text { Gemcitabine/cisplatin }\end{array}$ & 27.3 versus 24.3 months $^{a}$ & NA & NA \\
\hline & ELCC (17) & 60 & Osimertinib & platinum-pemetrexed & NA & NA & 19.3 months \\
\hline & Noonan and Camidge (18) & 343 & Crizotinib & platinum-pemetrexed & a & NA & 10.9 versus 7.0 months \\
\hline & Shaw et al. (19) & 130 & Ceritinib & NA & NA & NA & 7 months \\
\hline \multirow[t]{4}{*}{$\begin{array}{l}\text { Antiangiogenic } \\
\text { agents }\end{array}$} & Sandler et al. (28) & 878 & Bevacizumab + Paclitaxel + carboplatin & Paclitaxel + carboplatin & $\begin{array}{l}12.3 \text { versus } 10.3 \text { months } \\
(p=0.003)\end{array}$ & NA & $\begin{array}{l}6.2 \text { versus } 4.5 \text { months } \\
(p<0.001)\end{array}$ \\
\hline & Garon et al (32) & 1,253 & Ramucirumab + Docetaxel & Docetaxel + Placebo & $\begin{array}{l}10.5 \text { versus } 9.1 \text { months } \\
(p=0.023)\end{array}$ & NA & $\begin{array}{l}4.5 \text { versus } 3.0 \text { months } \\
(p<0.0001)\end{array}$ \\
\hline & Blumenschein et al. (33) & 52 & Sorafenib & NA & 6.7 months & NA & 2.7 months \\
\hline & Heist et al. (37) & 125 & Sunitinib & $\begin{array}{l}\text { Sunitinib + Pemetrexed } \\
\text { OR } \\
\text { Pemetrexed }\end{array}$ & $\begin{array}{l}8.0 \text { versus } 6.7 \text { versus } \\
10.5 \text { months }\end{array}$ & NA & $\begin{array}{l}3.3 \text { versus } 3.7 \text { versus } \\
4.9 \text { months }\end{array}$ \\
\hline
\end{tabular}

${ }^{a}$ not statistically significantly different.

NA, non-applicable. 


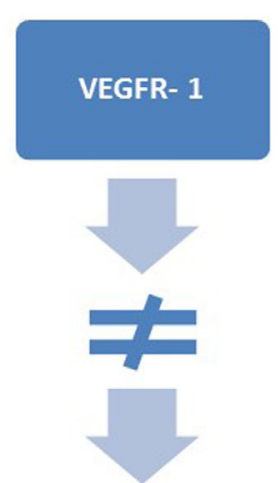

Recruitment of hematopoietic stem cells and for the migration of monocytes and macrophages.
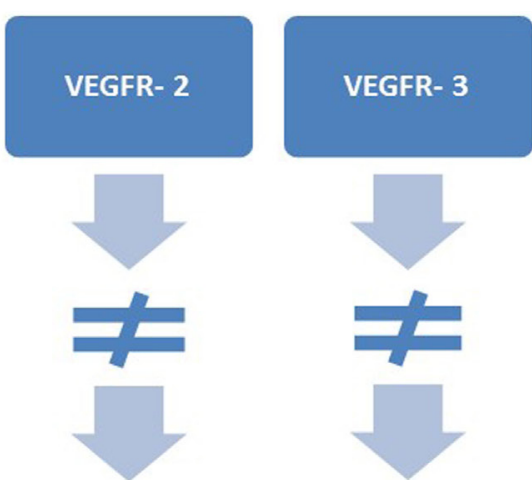

Stimulates proliferation, migration and survival migration and survival
of endothelial cells and of endothelial cells and
increases vascular permeability.

Stromal recruitment affecting tumor growth,

angiogenesis, invasion and metastasis.
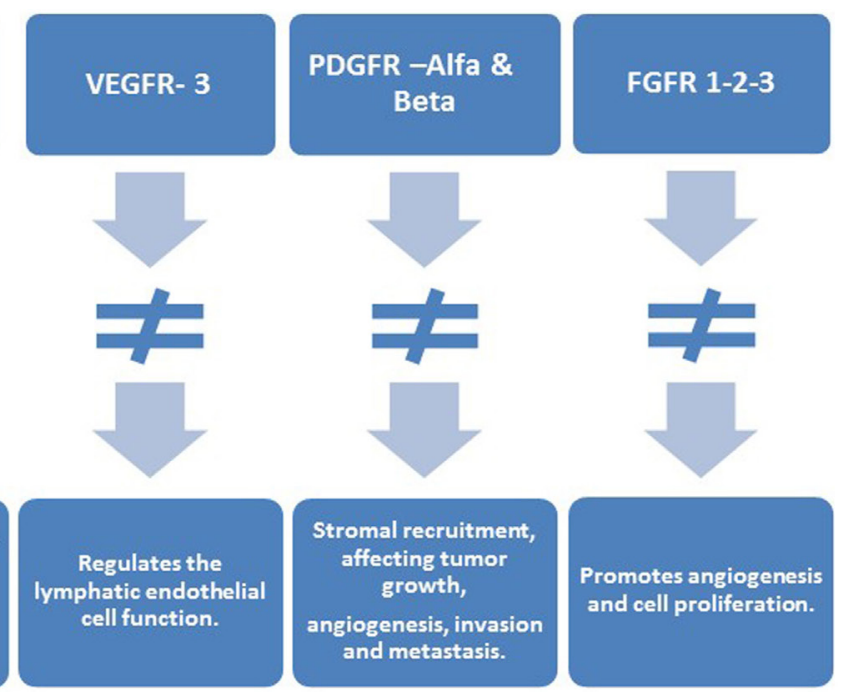

Arrows show the function of the activated receptors

$=/=$ Indicates the functions that are blocked by nintedanib

FIGURE 1 | Mechanism of action of nintedanib in lung cancer treatment.

In vitro studies showed that treatment with nintedanib induced proliferation arrest and apoptosis in endothelial cells, smooth muscle cells, and pericytes, cell types involved in angiogenesis, through the inhibition of both AKT and mitogen-activated protein kinases signaling pathways, resulting in an overexpression of the apoptosis marker cleaved caspase-3 (43).

Moreover, in vivo studies performed in human NSCLC xenografts have confirmed these results. One of the studies showed that at well-tolerated doses, nintedanib was highly active and demonstrated additive effects in combination with the cytotoxic drugs docetaxel or pemetrexed (42). In addition, in another study, nintedanib alone and in combination with standard chemotherapy showed a potent inhibition of proliferation and increased apoptosis of tumor cells in NSCLC xenografts that were poor responders to bevacizumab and resistant to platinum doublet chemotherapy (46). It demonstrated rapid changes in tumor vessel architecture, such as reduction of vessel permeability and perfusion, and microvessel density. Intracellularly, the inhibitory effect of nintedanib was found to be markedly sustained, with inhibition of VEGF receptor activation for at least $32 \mathrm{~h}$ after being treated for $1 \mathrm{~h}$ with nintedanib, suggesting slow receptor dissociation kinetics and sustained inhibition (43). There was no association with an increased expression of the epithelial mesenchymal transition (EMT) markers, a common mechanism of resistance to antiangiogenic therapies (46).

Another recent study evaluating the co-treatment of nintedanib with small interfering RNAs against six specific genes involved in EMT has shown that this molecule is able to do a downregulation of SYDE1 and ZEB1, and this sensitizes the cell's response to the drug in terms of EMT reversal (47). Additionally, in vitro and in vivo studies have evaluated the toxic potential of nintedanib, showing a tolerable safety profile of this compound, excluding any severe cardiovascular, respiratory, or neurological adverse effects, as well as any mutagenic potential of nintedanib (48).

Furthermore, the combination potential of nintedanib with PD-1 antagonists was explored in an in vivo combination experiments in two syngeneic murine tumor models. The murine tumor cell lines CT-26 and 4T1 were injected subcutaneously into female mice and subsequently treated with RMP1-14, a murine anti PD-1, nintedanib, or RMP1-14/nintedanib. Single agent treatment of CT-26 subcutaneous tumors with RMP1-14 resulted in antitumor effect with treated to control values of $45 \%$ and nintedanib resulted in a $63 \%$. The combination treatment group after 24 days showed a value of $34 \%$. Additionally, the use of nintedanib in the anti PD-1 refractory model $4 \mathrm{~T} 1$ showed a synergistic combinatorial antitumor effect. The combination of angiogenic and immune checkpoint inhibition is an attractive opportunity to improve overall response rates and efficacy based on the dual roles of angiogenic factors in blood vessel formation and immune regulation (49).

\section{PHASE I AND PHASE II CLINICAL TRIALS}

The tolerability of nintedanib has been studied in different kinds of neoplasm, such as ovarian cancer, NSCLC, breast cancer, colorectal cancer, urothelial carcinoma, and head and neck cancer (50). In a phase I open-label, dose-escalation trial, Doebele et al. studied the combination of this MATKI with paclitaxel and carboplatin in chemotherapy-naïve advanced NSCLC (51). Twenty-six patients enrolled and received nintedanib at the starting dose of $50 \mathrm{mg}$ twice daily on days $2-21$ in association with $200 \mathrm{mg} / \mathrm{m}^{2}$ paclitaxel 
and area under the curve 5 of carboplatin on day 1 of each 21-day cycle. Overall, $84.6 \%(n=22)$ experienced a partial response or stable disease without confirmation, and $26.9 \%(n=7)$ achieved a confirmed partial response. The treatment was well tolerated with liver enzyme elevations, thrombocytopenia, abdominal pain, and rash being the dose-limiting toxicities (DLT) (Table 2).

In another dose-escalation phase I/II trial, 26 patients with advanced NSCLC previously treated with first-line platinumbased chemotherapy, received nintedanib in association with pemetrexed. Patients received a starting dose of nintedanib of $100 \mathrm{mg}$ twice daily on days 2-21 in association with $500 \mathrm{mg} / \mathrm{m}^{2}$ of pemetrexed on day 1 of a 21-day cycle. Similar to the previous studies, the resultant maximum tolerated dose (MTD) of nintedanib was established at $200 \mathrm{mg}$ twice daily. Moreover, of the enrolled patients, 1 had a complete response, 13 had stable response, and 8 patients showed progressive disease. The median PFS was approximately 5.4 months. A good safety profile was confirmed, with fatigue, anorexia, and ALT increase being the most frequent grade 3 drug-related adverse events (52) (Table 2). Moreover, in a Japanese trial, the same MTD of nintedanib (200 mg twice daily) was established and a manageable safety profile and similar efficacy results as the previous studies were found (53).

Okamoto et al. evaluated in a phase I trial, the combination of nintedanib with docetaxel in advanced NSCLC patients who had been previously treated. Forty-two patients $(17 \mathrm{BSA}<1.5$, $25 \mathrm{BSA} \geq 1.5$ ) were treated. The MTD of nintedanib was 150 and $200 \mathrm{mg}$ twice daily in patients with BSA less than 1.5 and BSA greater than or equal to 1.5 , respectively, in combination with $75 \mathrm{mg} / \mathrm{m}^{2}$ of docetaxel. They found encouraging efficacy results, yielding a $73.7 \%$ of disease control rate. Furthermore, DLT, all grade 3 hepatic enzymes elevations, occurred in only one-third of the enrolled patients. All hepatic enzyme elevations were reversible and manageable with dose reduction or discontinuation. The main drug-related adverse events included neutropenia (95\%), leukopenia $(83 \%)$, fatigue $(76 \%)$, alopecia $(71 \%)$, decreased appetite $(67 \%)$, and elevations in alanine aminotransferase and aspartate aminotransferase (64\%) (40) (Table 2).

Also, a phase II double-blind study assessed the efficacy, safety, and tolerability of nintedanib in stage IIIB/IV NSCLC. The 73 patients recruited tolerated the continuous treatment and had no significant difference in efficacy between treatment arms (nindetanib $250 \mathrm{mg}$ twice a day versus $150 \mathrm{mg}$ twice a day). The median PFS was 6.9 weeks and the median OS was 21.9 weeks with no significant difference between the two groups; the disease control rate was 59\% (54) (Table 2).

\section{PHASE III TRIALS}

The LUME-Lung 1 trial (NCT00805194) is a multinational, randomized, placebo-controlled phase 3 trial that assessed the efficacy and safety of the combination of nintedanib and docetaxel in patients with stage IIIB/IV NSCLC progressing after first-line chemotherapy. Patients were assigned to docetaxel $75 \mathrm{mg} / \mathrm{m}^{2}$ by intravenous infusion on day 1 in addition to nintedanib $200 \mathrm{mg}$ twice daily orally or matching placebo on days 2-21, every 3 weeks. The primary endpoint was PFS, which was assessed by an independent central review, analyzed by intention to treat after 714 events in all patients. As key secondary outcome, OS was predefined and analyzed on an intention-to-treat basis in a prespecified, stepwise, fixed-sequence order: first, in a predefined group of patients with adenocarcinoma and poor prognosis (i.e., time elapsed since start of first-line therapy of less than 9 months until randomization into the trial); second, in patients with adenocarcinoma; and finally, in all patients regardless of histology. Other secondary outcomes were investigator-assessed PFS, tumor response by central review and investigator assessment, safety, and tolerability.

The study met its primary endpoint demonstrating a statistically significant improvement in PFS that translated into a $21 \%$ reduction in risk of progression (55). The PFS according to central independent review was significantly longer in nintedanib plus docetaxel group than in docetaxel plus placebo group (median PFS 3.4 versus 2.7 months; HR 0.79; 95\% CI 0.68-0.92; $p=0.0019$ ), with a more pronounced benefit in patients with adenocarcinoma histology (median PFS 4.2 versus 1.5 months; HR 0.68; 95\% CI 0.54-0.84; $p=0.0005$ ). Also, the subset of patients with adenocarcinoma and poor prognosis had a median PFS of 4.2 months in the docetaxel plus nintedanib group versus 1.6 months in the docetaxel plus placebo group (HR 0.67; 95\% CI $0.43-1.04, p=0.0725$ ) (56).

Even though, in the total population of patients there was only a trend in favoring the combination of docetaxel and nintedanib (median OS 10.1 versus 9.1 months; HR 0.94; 95\% CI 0.83-1.05; $p=0.2720$ ), in adenocarcinoma subgroup there was a significant difference in OS (median OS 12.6 versus 10.3 months; HR 0.83; 95\% CI 0.70-0.99; $p=0.0359$ ). Improvement was also observed in patients with adenocarcinoma histology and poor prognosis; the median OS was longer in the docetaxel plus nintedanib group compared with the docetaxel plus placebo group (median OS 10.9 months versus 7.9 months; HR 0.75 ; 95\% CI $0.60-0.92$; $p=0.0073$ ) (56). The intent-to-treat analysis of OS in all studied patients showed a 1-month improvement that did not reach statistical significance; however, when adjusted to the sum of longest diameters of target lesions, a significant OS benefit was seen (55).

The tolerability profile was similar to that shown in phase I/II clinical trials. The adverse events that were more common in the docetaxel plus nintedanib group than the docetaxel plus placebo group were: diarrhea, increases of transaminases, nausea, decreased appetite, and vomiting, with only a $18.6 \%$ requiring dose reduction (56). Also, a study determined the impact on tumor growth over time as a treatment effect, with a specific focus on patients with poor prognosis (i.e., time of progression less than 9 months and who had progressive disease as best response to first-line treatment). The use of nintedanib and docetaxel showed a significant reduction in tumor burden and tumor growth over time compared to docetaxel in patients with adenocarcinoma histology and in the group of patients with the poorest prognosis (57) (Table 2).

Furthermore, Heigener et al. performed an analysis of adenocarcinoma population in the LUME-Lung 1 to determine if first-line treatment could influence subsequent outcomes for nintedanib and docetaxel arm. In the study, the efficacy outcomes, 
TABLE 2 | From phase I to phase III clinical trials on nintedanib.

\begin{tabular}{|c|c|c|c|c|c|c|c|c|c|c|c|c|}
\hline \multirow{2}{*}{$\begin{array}{l}\text { Clinical } \\
\text { trial } \\
\text { (phase) }\end{array}$} & \multirow{2}{*}{ Reference } & \multirow[t]{2}{*}{ Patient characteristics } & \multirow[t]{2}{*}{$n$} & \multirow[t]{2}{*}{ Drug combination } & \multirow{2}{*}{$\begin{array}{l}N \text { dose/ } \\
\text { frequency }\end{array}$} & \multicolumn{3}{|c|}{ Response $n(\%)$} & \multirow{2}{*}{$\begin{array}{l}\text { Stable } \\
\text { disease }\end{array}$} & \multirow[t]{2}{*}{ Progression } & \multirow[t]{2}{*}{ Median PFS } & \multirow[t]{2}{*}{ Median OS } \\
\hline & & & & & & $\begin{array}{c}\text { Stable } \\
\text { disease } \\
\text { or partial } \\
\text { response }\end{array}$ & $\begin{array}{c}\text { Partial } \\
\text { response }\end{array}$ & $\begin{array}{l}\text { Complete } \\
\text { response }\end{array}$ & & & & \\
\hline । & $\begin{array}{l}\text { Doebele et al. } \\
\text { (51) }\end{array}$ & $\begin{array}{l}\text { Chemotherapy-naïve advanced } \\
\text { NSCLC }\end{array}$ & 26 & Paclitaxel + carboplatin $+\mathrm{N}$ & $50 \mathrm{mg} / 2 \mathrm{id}$ & $22(84.6)$ & $7(26.9)$ & 0 & $\begin{array}{c}15 \\
(57.7)\end{array}$ & NA & NA & NA \\
\hline |/II & Ellis et al. (52) & $\begin{array}{l}\text { Advanced NSCLC preciously } \\
\text { treated with first-line platinum-based } \\
\text { chemotherapy }\end{array}$ & 26 & Pemetrexed + N & $100 \mathrm{mg}^{\mathrm{a} / 2} \mathrm{id}$ & NA & NA & $1(3.8)$ & $13(50)$ & $8(30.8)$ & 5.4 months & NA \\
\hline । & $\begin{array}{l}\text { Okamoto et al. } \\
(40)\end{array}$ & Advanced NSCLC previously treated & 42 & Docetaxel + N & $\begin{array}{l}150- \\
200 \mathrm{mg} / 2 \mathrm{id}\end{array}$ & $31(73.7)$ & NA & NA & NA & NA & NA & NA \\
\hline$\|$ & Reck et al. (54) & Stage IIIB/IV NSCLC & 73 & $\mathrm{~N}$ & $\begin{array}{l}150 \mathrm{or} \\
250 \mathrm{mg} / 2 \mathrm{id}\end{array}$ & $43(59)$ & & & & & 6.9 weeks & 21.9 weeks \\
\hline \multirow[t]{4}{*}{ III } & $\begin{array}{l}\text { LUME-Lung } 1 \\
\text { Trial (55-57) }\end{array}$ & $\begin{array}{l}\text { Stage IIIB/IV NSCLC progressing after } \\
\text { first-line chemotherapy }\end{array}$ & 1,314 & Docetaxel + N & $200 \mathrm{mg} / 2 \mathrm{id}$ & NA & NA & NA & NA & NA & $\begin{array}{l}3.4 \text { versus } \\
2.7 \text { months+ }\end{array}$ & $\begin{array}{l}10.1 \text { versus } \\
9.1 \text { months++ }\end{array}$ \\
\hline & $\begin{array}{l}\text { Campos- } \\
\text { Gomez and } \\
\text { Campos- } \\
\text { Gomez (61) }\end{array}$ & $\begin{array}{l}\text { Advanced NSCLC progressing after } \\
\text { one line of chemotherapy }\end{array}$ & 17 & Docetaxel + N & $200 \mathrm{mg} / 2 \mathrm{id}$ & NA & $13(81.25)$ & NA & $3(18.75)$ & NA & NA & 42 months \\
\hline & $\begin{array}{l}\text { Garcia Montes } \\
\text { (62) }\end{array}$ & $\begin{array}{l}\text { Advanced lung adenocarcinoma } \\
\text { who progressed to first-line } \\
\text { treatment + bevacizumab }\end{array}$ & 99 & Docetaxel + N & $200 \mathrm{mg} / 2 \mathrm{id}$ & 79 (79.6) & $52(53)$ & NA & $\begin{array}{c}26 \\
(26.5)\end{array}$ & $16(16.3)$ & NA & NA \\
\hline & $\begin{array}{l}\text { LUME-Lung } 2 \\
\text { Trial (63) }\end{array}$ & $\begin{array}{l}\text { Advanced non-squamous NSCLC } \\
\text { previously treated with chemotherapy }\end{array}$ & 713 & Pemetrexed + N & 200 mg/2 id & $435(61)$ & NA & NA & NA & NA & $\begin{array}{l}4.4 \text { versus } \\
3.6 \text { months }\end{array}$ & $\begin{array}{l}12.2 \text { versus } \\
12.7 \text { months }\end{array}$ \\
\hline
\end{tabular}

N, nintedanib; $n$, number of patients enrolled; NA, non-applicable; +, 4.2 months when considering group of patients with adenocarcinoma; ++, 12.6 versus 10.3 months when considering group of patients with adenocarcinoma,

$p=0.0359$.

alnitial dose. 
the OS benefit, and the frequency of adverse events were similar regardless of prior treatments with taxanes, pemetrexed, or bevacizumab (58).

Popat et al. confirmed LUME-Lung-1 findings in a metaanalysis of nine studies. They estimated a probability of $70 \%$ for nintedanib plus docetaxel being the best second-line treatment with regard to OS and PFS (59). Based on these findings, the European Medicines Agency approved in November 2014 the combination of nintedanib with docetaxel for the second-line treatment of adenocarcinoma patients (60). Furthermore, using patient-reported outcomes [i.e., 30-item European Organisation for Research and Treatment of Cancer Core Quality of Life (QoL) Questionnaire and its 13-item lung cancer-specific supplement] to complement the objective measures of efficacy and safety, this trial allowed the assessment of patients' subjective perception of their symptom burden and health-related QoL. This analysis demonstrated that the survival benefits achieved in the LUME-Lung 1 trial were not at the expense of patients' QoL. No significant differences in the PRO composites for cough, dyspnea, or pain were observed between the treatment groups (56).

Moreover, a cohort of NSCLC Mexican patients receiving nintedanib with docetaxel demonstrated efficacy and that was well tolerated; $81.25 \%$ had a partial response and $18.75 \%$ had stable disease (61). Also, a descriptive trial used the clinical data collection of patients with advanced lung adenocarcinoma who progressed to first-line treatment plus bevacizumab included in the compassionate-use program of nintedanib. The primary objective of the study was to describe the characteristics of the patients and their tumors, including previous therapies. The secondary objectives were to estimate the time under nintedanib treatment and the response rate and to evaluate the safety of this new treatment in daily clinical practice. From the 99 patients who were included, the objective response rate was $53 \%$, stable disease $26.5 \%$, disease progression $16.3 \%$, and $4 \%$ were non-evaluable. Also, the disease control rate was $79.6 \%$. The majority of patients had adequate tolerance, similar to the results obtained in LUME-Lung 1, mostly toxicities grades 1-2. However, the retrospective design of the study and the biased criteria of the investigator could have influenced in the overestimated responses (62).

Another phase III controlled randomized trial, LUME-Lung 2 (NCT00806819) evaluated the use of nintedanib in combination with pemetrexed $\left(500 \mathrm{mg} / \mathrm{m}^{2}\right)$ and compared with pemetrexed $\left(500 \mathrm{mg} / \mathrm{m}^{2}\right)$ plus placebo in patients with advanced, nonsquamous NSCLC previously treated with chemotherapy (63). The primary endpoint was the same as LUME-Lung 1, while the secondary endpoints included OS, investigator-assessed PFS,

\section{REFERENCES}

1. Howlader N, Noone AM, Krapcho M, Miller D, Bishop K, Altekruse SF, et al., editors. SEER Cancer Statistics Review, 1975-2013. Bethesda, MD: National Cancer Institute (2016). Available from: http://seer.cancer.gov/ csr/1975_2013/ response rate, safety, and QoL. Even though the enrollment was halted after randomizing 713 patients based on a planned futility analysis, the study met its primary endpoint. The nintedanib arm had a significant better PFS (median PFS 4.4 versus 3.6 months compared with placebo; HR 0.83; 95\% CI 0.70-0.99; $p=0.0435$ ); however, this difference was not translated into an OS benefit (12.2 versus 12.7 months; HR 1.03; 95\% CI 0.85-1.24; $p=0.7921)$. Moreover, disease control was also significantly improved in the nintedanib arm (61 versus 53\%, odds ratio $1.37, p=0.039)$. Also, in this study, nintedanib showed a higher incidence of grade 3 increases in liver enzymes and gastrointestinal events, which resolved with dose reduction and supportive treatment (56). In contrast to other antiangiogenic agents, no grade $3 / 4$ hypertension or hand-foot syndrome was reported (54) (Table 1).

Additionally, the association between plasma levels of VEGF, FGF, and PDGF was evaluated, both baseline and after treatment with nintedanib plus docetaxel, as well as disease control rate, PFS, and OS, among 38 patients with NSCLC. A higher percentage change reduction in PDGF after treatment was associated with a longer PFS and a higher percentage change in FGF was associated with a longer OS. Also, a higher reduction of plasma levels of FGF and PDGF was associated with better clinical outcomes (64).

Several clinical trials involving nintedanib are ongoing, including a phase III study (NCT02299141), that will evaluate the effectiveness of nintedanib in molecularly selected NSCLC patients and investigate the potential role of some genes (VEGFR1-3, PDGFR-A, PDGFR-B, and FGFR1-3) that might be involved in the regulation of mechanisms of acquired resistance to antiangiogenic agents. Results are expected by June 2017.

\section{CONCLUSION}

Nintedanib might be a good treatment option that fulfils the unmet need for effective, well-tolerated treatment options in advanced NSCLC and alleviate the disease burden for a broad selection of patients. The significant improvement in PFS in the overall population and the subgroup of patients with adenocarcinoma observed with the addition of nintedanib to cytotoxic drug therapy represents an attractive second-line treatment option. Moreover, the safety profile of this MATKI is manageable, giving this new treatment option great potential as an emerging combination for the management of NSCLC.

\section{AUTHOR CONTRIBUTIONS}

All authors contributed equally to this paper. All authors agreed to be accountable for the content of the work. 
4. Siegel RL, Miller KD, Jemal A. Cancer statistics, 2016. CA Cancer J Clin (2016) 66(1):7-30. doi:10.3322/caac.21332

5. Herbst RS, Heymach JV, Lippman SM. Lung cancer. N Engl J Med (2008) 359(13):1367-80. doi:10.1056/NEJMra0802714

6. Ettinger DS, Wood DE, Akerley W, Bazhenova LA, Borghaei H, Camidge DR, et al. NCCN Clinical Practice Guidelines in Oncology (NCCN Guidelines ${ }^{\circledR}$ ): Non-Small Cell Lung Cancer. Version 4. (2016).

7. Stinchcombe TE, Socinski MA. Considerations for second-line therapy of non-small cell lung cancer. Oncologist (2008) 13(Suppl 1):28-36. doi:10.1634/ theoncologist.13-S1-28

8. Gridelli C, Ardizzoni A, Ciardiello F, Hanna N, Heymach JV, Perrone F, et al. Second-line treatment of advanced non-small cell lung cancer. J Thorac Oncol (2008) 3(4):430-40. doi:10.1097/JTO.0b013e318168c815

9. Johnson DH, Fehrenbacher L, Novotny WF, Herbst RS, Nemunaitis JJ, Jablons DM, et al. Randomized phase II trial comparing bevacizumab plus carboplatin and paclitaxel with carboplatin and paclitaxel alone in previously untreated locally advanced or metastatic non-small-cell lung cancer. J Clin Oncol (2004) 22(11):2184-91. doi:10.1200/JCO.2004.11.022

10. Novello S, Kaiser R, Mellemgaard A, Douillard JY, Orlov S, Krzakowski M, et al. Analysis of patient-reported outcomes from the LUME-Lung 1 trial: a randomised, double-blind, placebo-controlled, phase III study of second-line nintedanib in patients with advanced non-small cell lung cancer. Eur J Cancer (2015) 51(3):317-26. doi:10.1016/j.ejca.2014.11.015

11. Yang JC, Wu YL, Schuler M, Sebastian M, Popat S, Yamamoto N, et al. Afatinib versus cisplatin-based chemotherapy for EGFR mutation-positive lung adenocarcinoma (LUX-Lung 3 and LUX-Lung 6): analysis of overall survival data from two randomised, phase 3 trials. Lancet Oncol (2015) 16(2):141-51. doi:10.1016/S1470-2045(14)71173-8

12. Jemal A, Siegel R, Ward E, Hao Y, Xu J, Murray T, et al. Cancer statistics, 2008. CA Cancer J Clin (2008) 58(2):71-96. doi:10.3322/CA.2007.0010

13. Scagliotti G, Hanna N, Fossella F, Sugarman K, Blatter J, Peterson P, et al. The differential efficacy of pemetrexed according to NSCLC histology: a review of two phase III studies. Oncologist (2009) 14(3):253-63. doi:10.1634/ theoncologist.2008-0232

14. Paulus V, Avrillon V, Perol M. The safety and efficacy of ramucirumab in combination with docetaxel in the treatment of lung cancer. Expert Rev Anticancer Ther (2016) 16(11):1119-29. doi:10.1080/14737140.2016.1241147

15. Zhou C, Wu YL, Chen G, Feng J, Liu X-Q, Wang C, et al. Final overall survival results from a randomised, phase III study of erlotinib versus chemotherapy as first-line treatment of EGFR mutation-positive advanced non-small-cell lung cancer (OPTIMAL, CTONG-0802). Ann Oncol (2015) 26(9):1877-83. doi:10.1093/annonc/mdv276

16. Yang JC-H, Sequist LV, Schuler MH, Mok T, Yamamoto N, O’Byrne KJ, et al. Overall survival in patients with advanced non-small-cell lung cancer harbouring common (del19/L858R) EGFR mutations: pooled analysis of two large open-label phase III studies (LUX-lung 3 and LUX-lung 6) comparing afatinib with chemotherapy. 2014 ASCO Annual Meeting. J Clin Oncol (2014) 32(5):abstr8004.

17. Osimertinib Given as First-line Treatment May Alter Biology of EGFR-Mutated Non-Small-Cell Lung Cancer. Geneva: European Lung Cancer Conference 2016 (2016).

18. Noonan SA, Camidge DR. PROFILE 1014: lessons for the new era of lung cancer clinical research. Transl Lung Cancer Res (2015) 4(5):642-8. doi:10.3978/ j.issn.2218-6751.2015.05.02

19. Shaw AT, Kim DW, Mehra R, Tan DS, Felip E, Chow LQ, et al. Ceritinib in ALKrearranged non-small-cell lung cancer. N Engl J Med (2014) 370(13):1189-97. doi:10.1056/NEJMoa1311107

20. Scagliotti GV, Bironzo P, Vansteenkiste JF. Addressing the unmet need in lung cancer: the potential of immuno-oncology. Cancer Treat Rev (2015) 41(6):465-75. doi:10.1016/j.ctrv.2015.04.001

21. Novello S, Barlesi F, Califano T, Cufer S, Ekman S, Giaj Levra M, et al. Metastatic non-small-cell lung cancer: ESMO clinical practice guidelines for diagnosis, treatment and follow-up. Ann Oncol (2016) 27(Suppl 5):v1-27. doi:10.1093/annonc/mdw326

22. Carmeliet P, Jain RK. Angiogenesis in cancer and other diseases. Nature (2000) 407(6801):249-57. doi:10.1038/35025220

23. Herbst RS. Therapeutic options to target angiogenesis in human malignancies. Expert OpinEmergDrugs (2006) 11(4):635-50. doi:10.1517/14728214.11.4.635
24. Makrilia N, Lappa T, Xyla V, Nikolaidis I, Syrigos K. The role of angiogenesis in solid tumours: an overview. Eur J Intern Med (2009) 20(7):663-71. doi:10.1016/j.ejim.2009.07.009

25. Amini A, Masoumi Moghaddam S, Morris DL, Pourgholami MH. The critical role of vascular endothelial growth factor in tumor angiogenesis. Curr Cancer Drug Targets (2012) 12(1):23-43. doi:10.2174/156800912798888956

26. Raica M, Cimpean AM. Platelet-derived growth factor (PDGF)/PDGF receptors (PDGFR) axis as target for antitumor and antiangiogenic therapy. Pharmaceuticals (Basel) (2010) 3(3):572-99. doi:10.3390/ph3030572

27. Saylor PJ, Escudier B, Michaelson MD. Importance of fibroblast growth factor receptor in neovascularization and tumor escape from antiangiogenic therapy. Clin Genitourin Cancer (2012) 10(2):77-83. doi:10.1016/ j.clgc.2012.01.010

28. Sandler A, Gray R, Perry MC, Brahmer J, Schiller JH, Dowlati A. Paclitaxelcarboplatin alone or with bevacizumab for non-small-cell lung cancer. N Engl $J$ Med (2006) 355(24):2542-50. doi:10.1056/NEJMoa061884

29. Soria JC, Mauguen A, Reck M, Sandler AB, Saijo N, Johnson DH, et al. Systematic review and meta-analysis of randomised, phase II/III trials adding bevacizumab to platinum-based chemotherapy as first-line treatment in patients with advanced non-small-cell lung cancer. Ann Oncol (2013) 24(1):20-30. doi:10.1093/annonc/mds590

30. Cortot AB, Audigier-Valette C, Molinier O, Le Moulec S, Barlesi F, Zalcman $\mathrm{G}$, et al. Weekly paclitaxel plus bevacizumab versus docetaxel as second or third line treatment in advanced non-squamous non-small cell lung cancer (NSCLC): results from the phase III study IFCT-1103 ULTIMATE. 2016 ASCO Annual Meeting. J Clin Oncol (2016) 34(Suppl):abstr9005.

31. Leighl NB, Zatloukal P, Mezger J, Ramlau R, Moore N, Reck M, et al. Efficacy and safety of bevacizumab-based therapy in elderly patients with advanced or recurrent nonsquamous non-small cell lung cancer in the phase III BO17704 study (AVAiL). J Thorac Oncol (2010) 5(12):1970-6. doi:10.1097/ JTO.0b013e3181f49c22

32. Garon EB, Ciuleanu TE, Arrieta O, Prabhash K, Syrigos KN, Goksel T, et al. Ramucirumab plus docetaxel versus placebo plus docetaxel for second-line treatment of stage IV non-small-cell lung cancer after disease progression on platinum-based therapy (REVEL): a multicentre, double-blind, randomised phase 3 trial. Lancet (2014) 384(9944):665-73. doi:10.1016/ S0140-6736(14)60845-X

33. Blumenschein GR Jr, Gatzemeier U, Fossella F, Stewart DJ, Cupit L, Cihon F, et al. Phase II, multicenter, uncontrolled trial of single-agent sorafenib in patients with relapsed or refractory, advanced non-small-cell lung cancer. JClin Oncol (2009) 27(26):4274-80. doi:10.1200/JCO.2009. 22.0541

34. Schiller JH, Flaherty KT, Redlinger M, Binger K, Eun J, Petrenciuc O, et al. Sorafenib combined with carboplatin/paclitaxel for advanced non-small cell lung caner: a phase I subset analysis. J Clin Oncol (2006) 24:7194. doi:10.1200/ jco.2006.24.18_suppl.7194

35. Scagliotti GV, Parikh P, von Pawel J, Biesma B, Vansteenkiste J, Manegold C, et al. Phase III study comparing cisplatin plus gemcitabine with cisplatin plus pemetrexed in chemotherapy-naive patients with advanced-stage non-small-cell lung cancer. J Clin Oncol (2008) 26(21):3543-51. doi:10.1200/JCO.2007.15.0375

36. Paz-Ares LG, Biesma B, Heigener D, von Pawel J, Eisen T, Bennouna J, et al. Phase III, randomized, double-blind, placebo-controlled trial of gemcitabine/ cisplatin alone or with sorafenib for the first-line treatment of advanced, nonsquamous non-small-cell lung cancer. J Clin Oncol (2012) 30(25):3084-92. doi:10.1200/JCO.2011.39.7646

37. Heist RS, Wang X, Hodgson L, Otterson GA, Stinchcombe TE, Gandhi L, et al. CALGB 30704 (Alliance): a randomized phase II study to assess the efficacy of pemetrexed or sunitinib or pemetrexed plus sunitinib in the second-line treatment of advanced non-small-cell lung cancer. J Thorac Oncol (2014) 9(2):214-21. doi:10.1097/JTO.0000000000000071

38. Groen HJ, Socinski MA, Grossi F, Juhasz E, Gridelli C, Baas P, et al. A randomized, double-blind, phase II study of erlotinib with or without sunitinib for the second-line treatment of metastatic non-small-cell lung cancer (NSCLC). Ann Oncol (2013) 24(9):2382-9. doi:10.1093/annonc/mdt212

39. Scagliotti GV, Krzakowski M, Szczesna A, Strausz J, Makhson A, Reck M, et al. Sunitinib (SU) in combination with erlotinib (E) for the treatment of advanced/metastatic non-small cell lung cancer (NSCLC): a phase III study. Ann Oncol (2010) 21(8):LBA6:viii3. doi:10.1093/annonc/mdq601 
40. Okamoto I, Miyazaki M, Takeda M, Terashima M, Azuma K, Hayashi H, et al. Tolerability of nintedanib (BIBF 1120) in combination with docetaxel: a phase 1 study in Japanese patients with previously treated non-smallcell lung cancer. J Thorac Oncol (2015) 10(2):346-52. doi:10.1097/JTO. 0000000000000395

41. Roth GJ, Heckel A, Colbatzky F, Handschuh S, Kley J, Lehmann-Lintz T, et al. Design, synthesis, and evaluation of indolinones as triple angiokinase inhibitors and the discovery of a highly specific 6-methoxycarbonyl-substituted indolinone (BIBF 1120). J Med Chem (2009) 52(14):4466-80. doi:10.1021/ jm900431g

42. Hilberg F, Brandstetter I. C7-03: efficacy of BIBF 1120, a potent triple angiokinase inhibitor, in models of human non-small cell lung cancer is augmented by chemotherapy. J Thorac Oncol (2007) 2(8):S380.

43. Hilberg F, Roth GJ, Krssak M, Kautschitsch S, Sommergruber W, TontschGrunt U, et al. BIBF 1120: triple angiokinase inhibitor with sustained receptor blockade and good antitumor efficacy. Cancer Res (2008) 68(12):4774-82. doi:10.1158/0008-5472.CAN-07-6307

44. Rolfo C, Raez LE, Bronte G, Santos ES, Papadimitriou K, Buffoni L, et al. BIBF 1120/ nintedanib: a new triple angiokinase inhibitor-directed therapy in patients with non-small cell lung cancer. Expert Opin Investig Drugs (2013) 22(8):1081-8. doi:10.1517/13543784.2013.812630

45. Dhillon S. Nintedanib: a review of its use as second-line treatment in adults with advanced non-small cell lung cancer of adenocarcinoma histology. Target Oncol (2015) 10(2):303-10. doi:10.1007/s11523-015-0367-8

46. Kutluk Cenik B, Ostapoff KT, Gerber DE, Brekken RA. BIBF 1120 (nintedanib), a triple angiokinase inhibitor, induces hypoxia but not EMT and blocks progression of preclinical models of lung and pancreatic cancer. Mol Cancer Ther (2013) 12(6):992-1001. doi:10.1158/1535-7163. MCT-12-0995

47. Huang RY, Kuay KT, Tan TZ, Asad M, Tang HM, Ng AH, et al. Functional relevance of a six mesenchymal gene signature in epithelial-mesenchymal transition (EMT) reversal by the triple angiokinase inhibitor, nintedanib (BIBF1120). Oncotarget (2015) 6(26):22098-113. doi:10.18632/oncotarget.4300

48. Roth GJ, Binder R, Colbatzky F, Dallinger C, Schlenker-Herceg R, Hilberg F, et al. Nintedanib: from discovery to the clinic. J Med Chem (2015) 58(3):1053-63. doi:10.1021/jm501562a

49. Hilberg F, Reschke M, Hofmann M, Kraut N. P2.01-045 - Nintedanib Improves Anti-Tumor Efficacy in Combination with Anti PD-1 in Syngeneic Tumor Models Sensitive and Refractory to IO Inhibition, in WCLC. J Thorac Oncol (2016) 12(1):S813. doi:10.1016/j.jtho.2016.11.1097

50. Mross K, Stefanic M, Gmehling D, Frost A, Baas F, Unger C, et al. Phase I study of the angiogenesis inhibitor BIBF 1120 in patients with advanced solid tumors. Clin Cancer Res (2010) 16(1):311-9. doi:10.1158/1078-0432. CCR-09-0694

51. Doebele RC, Conkling P, Traynor AM, Otterson GA, Zhao Y, Wind S, et al. A phase I, open-label dose-escalation study of continuous treatment with BIBF 1120 in combination with paclitaxel and carboplatin as first-line treatment in patients with advanced non-small-cell lung cancer. Ann Oncol (2012) 23(8):2094-102. doi:10.1093/annonc/mdr596

52. Ellis PM, Kaiser R, Zhao Y, Stopfer P, Gyorffy S, Hanna N. Phase I open-label study of continuous treatment with BIBF 1120, a triple angiokinase inhibitor, and pemetrexed in pretreated non-small cell lung cancer patients. Clin Cancer Res (2010) 16(10):2881-9. doi:10.1158/1078-0432.CCR-09-2944

53. Daga H, Takeda K, Okada H, Miyazaki M, Ueda S, Kaneda S, et al. Safety and efficacy of nintedanib (BIBF 1120) plus pemetrexed in Japanese patients with advanced or recurrent non-small cell lung cancer (NSCLC): a phase I study. J Clin Oncol (2013) 31(Suppl):abstr 8056.

54. Reck M, Kaiser R, Eschbach C, Stefanic M, Love J, Gatzemeier U, et al. A phase II double-blind study to investigate efficacy and safety of two doses of the triple angiokinase inhibitor BIBF 1120 in patients with relapsed advanced non-small-cell lung cancer. Ann Oncol (2011) 22(6):1374-81. doi:10.1093/ annonc/mdq618

55. Reck M, Novello S, Mellemgaard A, Orlov S, Kaiser R, Barrueco J, et al. Impact of tumor burden on the overall survival analysis of the lume-lung 1 study: a randomized, double-blind phase 3 trial of Nintedanib (Bibf 1120) + Docetaxel in Nsclc patients progressing after first-line chemotherapy. WCLC O16.01. J Thorac Oncol (2013) 8(11 suppl 2):S2-1348. doi:10.1097/01.JTO. 0000438438.14562.c8

56. Reck M, Kaiser R, Mellemgaard A, Douillard JY, Orlov S, Krzakowski M, et al. Docetaxel plus nintedanib versus docetaxel plus placebo in patients with previously treated non-small-cell lung cancer (LUME-Lung 1): a phase 3, double-blind, randomised controlled trial. Lancet Oncol (2014) 15(2):143-55. doi:10.1016/S1470-2045(13)70586-2

57. Reck M, Buchner H, Gottfried M, Novello S, Mellemgaard A, GaschlerMarkefski B, et al. Tumor growth over time in patients with non-small cell lung cancer (NSCLC) of adenocarcinoma histology (ACH) treated with nintedanib and docetaxel or placebo and docetaxel: analysis of data from the LUME-Lung 1 (LL1) study in ASCO Annual Metting. JClin Oncol (2015) 33(Suppl):abstr e19021.

58. Heigener D, Reck M, Mellemgaard A, Orlov S, Krzakowski M, Pawel JV, et al. MINI17.07 Efficacy of nintedanib/docetaxel after bevacizumab, pemetrexed or taxanes therapy in WCLC. J Thorac Oncol (2015) 10(9):S323-4. doi:10.1016/ S1556-0864(16)30011-9

59. Popat S, Mellemgaard A, Fahrbach K, Martin A, Rizzo M, Kaiser R, et al. Nintedanib plus docetaxel as second-line therapy in patients with non-smallcell lung cancer: a network meta-analysis. Future Oncol (2015) 11(3):409-20. doi: $10.2217 /$ fon. 14.290

60. European Medicines Agency. Vargatef, CHMP Assessment Report EMA/ CHMP/726072/2014. London, UK: European Medicines Agency, Science Medicines Health (2014).

61. Campos-Gomez S, Campos-Gomez KA. P3.01-070 Experience with Docetaxel plus Nintedanib with previously treated NSCLC patients: compannionate use program single institution in Mexico in WCLC - P3.01-070. J Thorac Oncol (2015) 10(9 Suppl 2):S662. doi:10.1016/S1556-0864(16)30012-0

62. Rodriguez J, Garcia V. P3.02a-032 Multicenter trial of Nintedanib in combination with Docetaxel in metastatic Lung Adenocarcinoma: expertise in the real-life setting. J Thorac Oncol (2017) 12(1 Suppl):S1181. doi:10.1016/j. jtho.2016.11.1662

63. Hanna NH, Kaiser R, Sullivan RN, Aren OR, Ahn M-J, Tiangco B, et al. LUME-lung 2: a multicenter, randomized, double-blind, phase III study of nintedanib plus pemetrexed versus placebo plus pemetrexed in patients with advanced nonsquamous non-small cell lung cancer (NSCLC) after failure of first-line chemotherapy in ASCO Annual Meeting. JClin Oncol (2013) 31(Suppl):abstr 8034.

64. Lee-Cervantes D, Cruz-Rico G, Michel-Tello D, RamÍrez-Tirado L, AmievaRivera E, Macedo-Pérez O, et al. P2.03b-083 soluble angiogenic factors as predictive biomarkers of response to Docetaxel plus Nintedanib as second line therapy in NSCLC. J Thorac Oncol (2017) 12(1 Suppl):S986.

Conflict of Interest Statement: The authors declare that the research was conducted in the absence of any commercial or financial relationships that could be construed as a potential conflict of interest.

Copyright (๔) 2017 Corrales, Nogueira, Passiglia, Listi, Caglevic, Giallombardo, Raez, Santos and Rolfo. This is an open-access article distributed under the terms of the Creative Commons Attribution License (CC BY). The use, distribution or reproduction in other forums is permitted, provided the original author $(s)$ or licensor are credited and that the original publication in this journal is cited, in accordance with accepted academic practice. No use, distribution or reproduction is permitted which does not comply with these terms. 